\title{
The Impact of the Bisubstituted Aromatics Functional Groups on the Inhibition of Methane Biosynthesis (Biogas)
}

\author{
Kalombo Kayembe, Lolofo Basosila, Pius T. Mpiana", Pole C. Sikulisimwa, Juliette K. Kabongo, \\ Damien S. T. Tshibangu, Dorothée D. Tshilanda, Rigobertine K. Tati \\ Department of Chemistry, Faculty of Science, University of Kinshasa, Kinshasa, Democratic Republic of the Congo \\ Email: "ptmpiana@yahoo.fr
}

Received September 29, 2012; revised October 26, 2012; accepted November 6, 2012

\begin{abstract}
Inhibitory compounds are often found to be the leading cause of anaerobic reactor upset and failure since they are present in substantial concentration in wastewaters and organic solid wastes. Among these inhibitory compounds, organic compounds are mentioned and more especially aromatic compounds. The purpose of this work was to evaluate the effect of bisubstituted aromatics functional groups on the methanogenic inhibition. The toxicity to acetoclastic methanogenic bacteria has performed in serum flasks, utilizing digested pig manure as inoculums, by measuring cumulative methane production. The results obtained indicate that some general relationships exist between the bisubstituted aromatic structures and their inhibitory effects on methanogenic bacteria. This demonstrates sufficiently that the grafting of hydrophobic or hydrophilic substituent on the benzene or monofunctional aromatic compound, make the obtained compound more or less toxic as the case and that in the same order of toxicity. A significant correlation was obtained indicating that the partitioning of bisubstituted aromatics into lipophilic membranes in bacteria may have a role in the inhibition of methane biosynthesis.
\end{abstract}

Keywords: Anaerobic Digestion; Methane; Inhibition; Bisubstituted Aromatic; Biosynthesis; Digested Pig Manure

\section{Introduction}

Anaerobic digestion involves the degradation and stabilization of organic materials under anaerobic conditions by microbial organisms and leads to formation of biogas (a mixture of carbon dioxide and methane, a renewable energy source) and microbial biomass. Anaerobic treatment provides a method of reducing pollution from agricultural and industrial operations while at the same time offsetting the operations' usage of fossil fuels. As one of the most efficient and least expensive waste treatment technologies for developing country such as DR CONGO, anaerobic digestion offers numerous significant advantages, such as low sludge production, fertilizer production, energy recovery and deforestation reduction [1-5].

Inhibitory substances are often found to be the leading cause of anaerobic reactor upset and failure since they are present in substantial concentration in wastewaters and organic solid wastes. A wide variety of substances have been reported to be inhibitory to methanogenic bacteria. Among these inhibitory compounds, organic compounds are mentioned and more especially aromatic compounds [6-8].

Aromatic compounds are naturally present in the en-

*Corresponding author. vironment as degradation products of lignin, tannins, phenolic amino acids, pigments and other aromatic compounds from plants. Human activity also contributes to the presence of aromatic compounds in the environment: waste incineration, petrochemical effluents, industries of paper manufacturing, pharmaceutical and chemical industries, pesticides etc. are, very important sources of aromatic pollution [8-10].

The presence of aromatic xenobiotic in the environment may create serious public health and environmental problems. Some aromatic compounds are mutagenic or carcinogenic and some may bioaccumulate. Additionally, synthetic aromatic compounds are often resistant to biodegradation and toxic to microorganisms [11,12].

Indeed, although the anaerobic biodegradability of aromatic compounds has been extensively studied, less attention has been given to the correlation of aromatic compounds structure and their toxic effects on the community of anaerobic bacteria. At our knowledge, few works are published on the methanogenic toxicity of aromatic compounds. Most of these works were performed with the granular sludge as inoculums from an industrial anaerobic reactor called "Upflow Anaerobic Sludge Bed” (UASB-reactor). Generally, the digesters are heated to about $30^{\circ} \mathrm{C}$ and more, but in this work di- 
gested pig manure from a laboratory scale digester was used as inoculum and the experiment was conducted at room temperature of an African tropical country $\left(27^{\circ} \mathrm{C} \pm\right.$ $\left.1^{\circ} \mathrm{C}\right)$.

The aim of this work was to determine, the effect of bisubstituted aromatic compounds functional groups, on the inhibition of biogas biosynthesis by acetoclastic methanogenic bacteria in digested pig manure and without heating the reactor.

To investigate the influence of two functional groups on the methanogenic toxicity, bifunctional aromatic compounds with identical functions and the other different in para position were taken. So, the influence of the second function on the toxicity of these bifunctional compounds can be studied in the absence of electronic and steric interactions between the two substituents. In this study, following aromatic compounds were tested: the parasubstituted toluenes (para-tolyles), and the para-substituted phenols and thiophenols.

\section{Materials and Methods}

\subsection{Biomass}

Pig manure from DAIPN farm of Nsele/KINSHASA (DR CONGO) was digested in laboratory scale digester during about six months. The digested pig manure was utilized as inoculums in our anaerobic toxicity tests. The sludge (digested ping manure) was not previously acclimated to any aromatic compounds.

Characteristic of inoculums: total suspended solid (TSS) concentration $91.10 \mathrm{~g} / \mathrm{L}$, VSS concentration 56.59 g/L, specific acetoclastic methanogenic activity 163.40 -

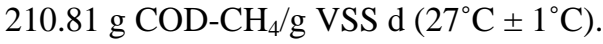

\subsection{Mineral Media}

The basal medium used in the anaerobic toxicity assay contained the following: $\mathrm{NaHCO}_{3}, 5000 \mathrm{mg} / \mathrm{L} ; \mathrm{NH}_{4} \mathrm{Cl}$, $280 \mathrm{mg} / \mathrm{L} ; \mathrm{CaCl}_{2} \cdot 2 \mathrm{H}_{2} \mathrm{O}, 10 \mathrm{mg} / \mathrm{L} ; \mathrm{K}_{2} \mathrm{HPO}_{4}, 250 \mathrm{mg} / \mathrm{L}$; $\mathrm{MgSO}_{4} \cdot 7 \mathrm{H} 2 \mathrm{O}, 100 \mathrm{mg} / \mathrm{L}$; yeast extract, $100 \mathrm{mg} / \mathrm{L}$; $\mathrm{H}_{3} \mathrm{BO}_{3}, 0.05 \mathrm{mg} / \mathrm{L} ; \mathrm{FeCl}_{2} \cdot 4 \mathrm{H}_{2} \mathrm{O}, 2 \mathrm{mg} / \mathrm{L} ; \mathrm{ZnCl}_{2}, 0.05$ $\mathrm{mg} / \mathrm{L} ; \mathrm{MnCl}_{2} \cdot 4 \mathrm{H}_{2} \mathrm{O}, 0.05 \mathrm{mg} / \mathrm{L} ; \mathrm{CuCl}_{2} \cdot 2 \mathrm{H}_{2} \mathrm{O}, 0.03 \mathrm{mg} / \mathrm{L}$; $\left(\mathrm{NH}_{4}\right) \mathrm{SeO}_{3} \cdot 5 \mathrm{H}_{2} \mathrm{O}, 0.05 \mathrm{mg} / \mathrm{L} ; \mathrm{AlCl}_{3} \cdot 6 \mathrm{H}_{2} \mathrm{O}, 2 \mathrm{mg} / \mathrm{L}$; $\mathrm{NiCl}_{2} \cdot 6 \mathrm{H}_{2} \mathrm{O}, 0.05 \mathrm{mg} / \mathrm{L} ; \mathrm{Na}_{2} \mathrm{SeO}_{3} \cdot 5 \mathrm{H}_{2} \mathrm{O}, 0.1 \mathrm{mg} / \mathrm{L}$; EDTA, $1 \mathrm{mg} / \mathrm{L}$; resazurin, $0.2 \mathrm{mg} / \mathrm{L}$; as well as $36 \% \mathrm{HCl}$ at $0.001 \mathrm{~mL} / \mathrm{L}, \mathrm{pH} 7.2[10,11]$.

\subsection{Aromatic Compounds}

The bifunctional aromatic compounds included: Toluène, p-Tolualdehyde, $\mathrm{p}$-Crésol et $\mathrm{p}$-Toluidine as para-substituted toluenes (Tolyles) and p-Nitrophénols, p-Thiocrésol, p-Chlorothiophénol, p-Crésol, p-Méthoxy-phénol, Phénol, p-Aminophenol and Hydroquinone as the parasubstituted phenols and thiophenols. Toluene and phenol were used, respectively, as reference for the two classes of aromatic compounds. All aromatic com- pounds were p.a. products.

\subsection{Anaerobic Toxicity Assay}

Specific acetoclastic methanogenic activity measurements were performed with 11 glass serum bottles sealed with butyl rubber septa. Digested pig manure $1.5 \mathrm{~g}$ VSS/L (volatile suspended solids per liter) has transferred to glass serum bottles containing $900 \mathrm{~mL}$ of basal medium and acetate from a neutralized stock solution ( $\mathrm{pH} 7$ ) to yield a final concentration of $4 \mathrm{~g}$ COD$\mathrm{CH}_{3} \mathrm{COONa} / \mathrm{L}$ (chemical oxygen demand per liter).

The required quantity of inhibitory compound was added to each flask to provide the toxic concentration to be investigated. No toxicant was added to the controls. The toxicant concentrations had chosen as to cause an inhibition of the acetoclastic activity ranging from $0 \%$ $100 \%[6,13]$.

The liquid was flushed with nitrogen gas for 5 minutes and the flask were sealed with rubber septum cap and placed in a reciprocating shaker at $27^{\circ} \mathrm{C} \pm 1^{\circ} \mathrm{C}$ (room temperature).

The specific methanogenic activity was calculated from the slope of the methane production versus time curve and the quantity of VSS. The compound concentration that caused $50 \%$ inhibition of the methanogenic activity had referred to as " $50 \%$ IC or $\mathrm{IC}_{50}$ ". All specific methanogenic activity measurements were conducted in triplicate. To determine the inhibition degree, the methanogenic activities of the control and samples con- taining inhibitory compounds were determined.

The methane gas volume produced had measured by serum bottle liquid displacement systems (Mariotte flask system) as previously described $[6,13,14]$.

\section{Results and Discussion}

\subsection{Inhibition of Acetoclastic Specific Methanogenic Activity}

All concentrations of aromatic compounds examined exerted an inhibitory effect on the specific acetoclastic methanogenic activity.

Figure 1 shows the decrease in specific methanogenic activity with the increasing of the hydroquinone concentration and typify the determination of $\mathrm{IC}_{50}$ values.

This figure illustrates the decrease of bacterial methanogenic activity in the presence of aromatic compound.

\subsection{Effect of the Functional Groups on the Methanogenic Toxicity}

The inhibition caused by various bifunctional benzenes 


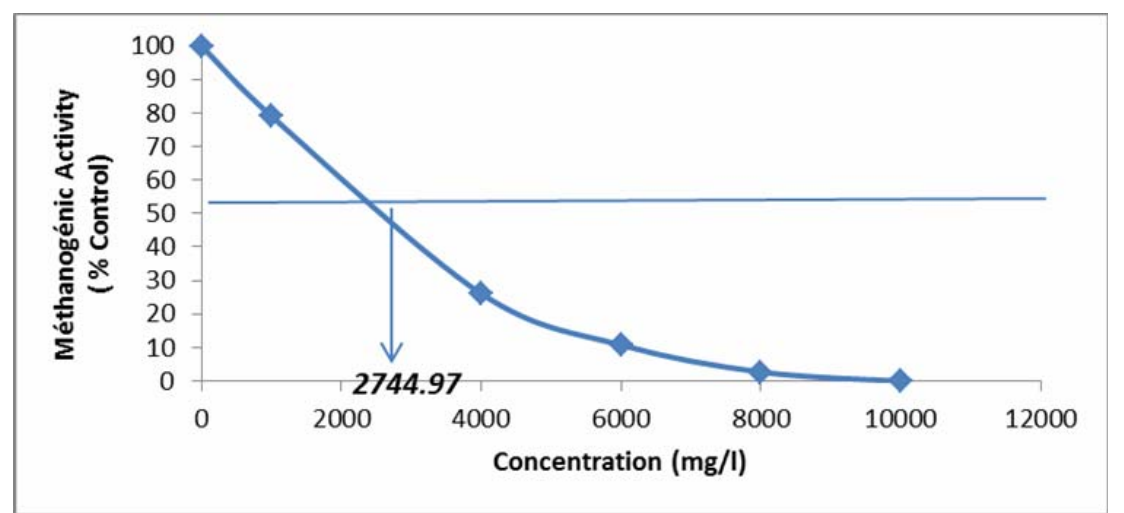

Figure 1. Methanogenic activity of digested pig manure exposed to Hydroquinone (p-Dihyroxybenzene) as a function of the hydroquinone concentration and the $\mathrm{IC}_{50}$ determination.

compounds on the activity of acetoclastic methanogenic bacteria compound was tested at various levels, from concentrations that were non toxic to those that were completely inhibitory to acetoclastic methanogenic activity, as typified in Figure 1. Tables $\mathbf{1}$ and $\mathbf{2}$ summarize the evaluated $\mathrm{IC}_{50}$ of the para-substituted toluenes and para-substituted (thio) phenols, ranked in decreasing order of toxicity.

The influence of the functional group on the methanogenic toxicity exhibited by the bisubstituted aromatic compounds is illustrated in Figures $\mathbf{2}$ and $\mathbf{3}$.

The results obtained indicate that some general relationships exist between the aromatic structures and their inhibitory effects on methanogenic bacteria. According to the Figures 3 and 4, the toxicity of the para-Tolyles and para-bisubstituted (thio) phenols increases, respectively, in the following order:

$\mathrm{NH}_{2}<\mathrm{OH}<\mathrm{CHO}<\mathrm{H}$ and $\mathrm{OH}<\mathrm{NH}_{2}<\mathrm{H}<\mathrm{CH}_{3} \mathrm{O}<$ $\mathrm{CH}_{3}<\mathrm{Cl}^{*}<\mathrm{CH}_{3}^{*}<\mathrm{NO}_{2}$

From these two sequences of increasing toxicity, it can be seen that the methanogenic toxicity varies with the functional group nature which is in the para position of the main function. In addition, it can be also noticed that thiocresol $\left(\mathrm{CH}_{3}^{*}\right)$ is more toxic than Cresol $\left(\mathrm{CH}_{3}\right)$ because it is more hydrophobic than the latter.

The obtained results are comparable to those reported in our previous work $[14,15]$ and by SIERRA and LETTINGA [12] for monosubstituted aromatic compounds. The addition of a functional group containing an oxygen or sulfur heteroatom to toluene or phenol, our reference compounds, decreased the bisubstituted aromatic compound toxicity as in the case of $\mathrm{NH}_{2}, \mathrm{OH}$, and CHO substitution. However, the addition of $\mathrm{CH}_{3} \mathrm{O}, \mathrm{CH}_{3}, \mathrm{Cl}^{*}$, $\mathrm{CH}_{3}^{*}$ and $\mathrm{NO}_{2}$ to phenol was associated with an increase in a compound toxicity.

This sufficiently demonstrates that the grafting of hydrophobic or hydrophilic substituent on the benzene or monofunctional aromatic compound, make the obtained compound more or less toxic.
Table 1. The $\mathrm{IC}_{50}$ values of various para-substituted toluenes (Tolyles).

\begin{tabular}{cccc}
\hline $\mathbf{N}^{\circ}$ & Compounds & $\mathbf{I C}_{\mathbf{5 0}}(\mathbf{m g} / \mathbf{L})$ & $\operatorname{logPoct}$ \\
\hline 1 & Toluene & $146.65 \pm 6.28$ & 2.73 \\
2 & p-Tolualdehyde & $503.95 \pm 5.95$ & 2.80 \\
3 & p-Cresol & $737.26 \pm 12.31$ & 1.96 \\
4 & p-Toluidine & $1260.47 \pm 38.80$ & 1.39 \\
\hline
\end{tabular}

Table 2. The $\mathrm{IC}_{50}$ values of various para-substituted (thio) phenols.

\begin{tabular}{cccc}
\hline $\mathbf{N}^{\circ}$ & Compounds & $\mathbf{I C}_{\mathbf{5 0}}(\mathbf{m g} / \mathbf{L})$ & $\operatorname{logPoct}$ \\
\hline 1 & p-Nitrophenol & $41.46 \pm 0.48$ & 1.91 \\
2 & p-Thiocresol & $523.01 \pm 15.92$ & 2.80 \\
3 & p-Chlorothiophenol & $638.26 \pm 29.90$ & $\mathrm{NA}^{*}$ \\
4 & p-Cresol & $737.26 \pm 12.31$ & 1.96 \\
5 & p-Methoxyphenol & $761.27 \pm 8.71$ & 1.58 \\
6 & Phenol & $1248.90 \pm 29.59$ & 1.47 \\
7 & p-Aminophenol & $180.39 \pm 38.80$ & 1.01 \\
8 & Hydroquinone & $2744.97 \pm 97.80$ & 0.59 \\
\hline
\end{tabular}

${ }^{*} \mathrm{NA}$, not available.

However, this behavior is only valid when the two substituents are not electronic and steric interactions and in the case of intramolecular hydrogen bonds the formation. This is possible, when the two substituents are in the para position relative to each other. Indeed, when the substituents are ortho or meta, interactions change the order of toxicity in one direction or an another.

\subsection{Correlation of the Methanogenic Toxicity with Aromatic Compounds Hydrophobicity}

Correlations between toxicity and partition coefficient within series of organic contaminants structurally related 


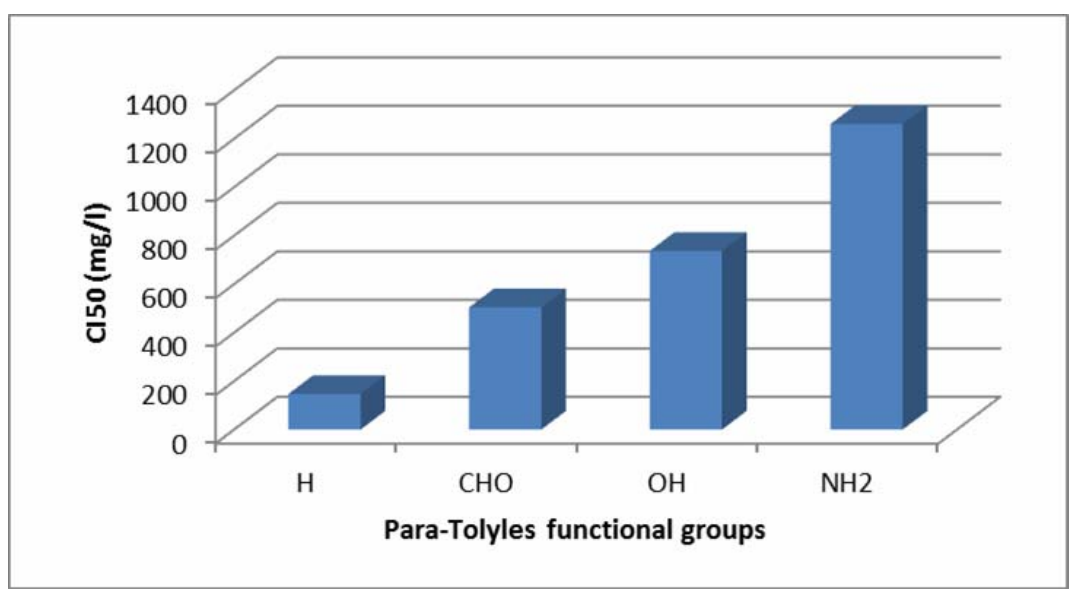

Figure 2. Variation of the methanogenic toxicity as a function of the para-substituted toluenes functional groups.

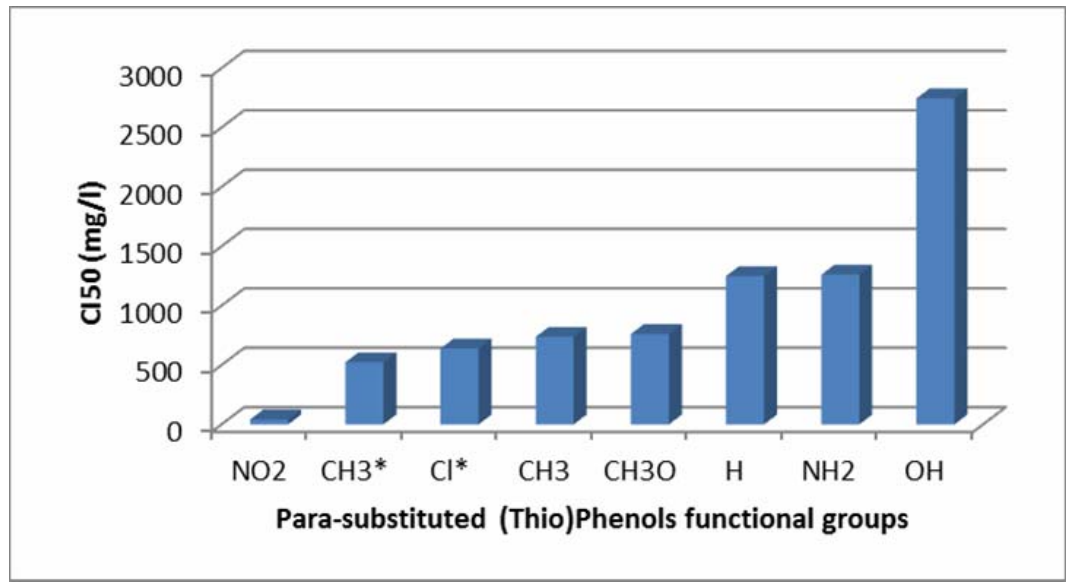

*Thiophenols functional groups.

Figure 3. Variation of the methanogenic toxicity as a function of para-substituted (thio) phenols functional groups.

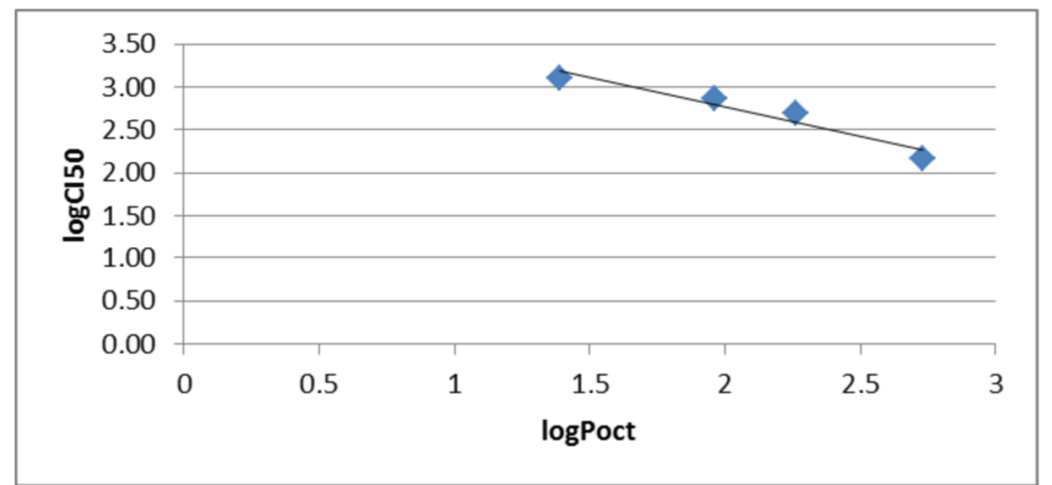

Figure 4. Effect of hydrophobicity on methanogenic toxicity for para-substituted toluenes $(r=-0.962445)$.

have been reported by several research groups using fish, ciliate or microorganism as tests organisms. Therefore, when comparing compounds that possess different types of substitutions, a perfect correlation with logPoct of the compound cannot be expected. A higher correlation could potentially be obtained by comparing compounds in homologues series [10,12].
To determine if the lipophilic character of bifunctional aromatics tested could be correlated with their methanogenic toxicity, the logarithm of the $\mathrm{IC}_{50}$ values of bisubstituted aromatics were plotted against the logarithm of the octanol-water partition coefficient (logPoct) of the aromatic compounds. Correlation study of toxicity-partition coefficient was performed on the bifunctional 


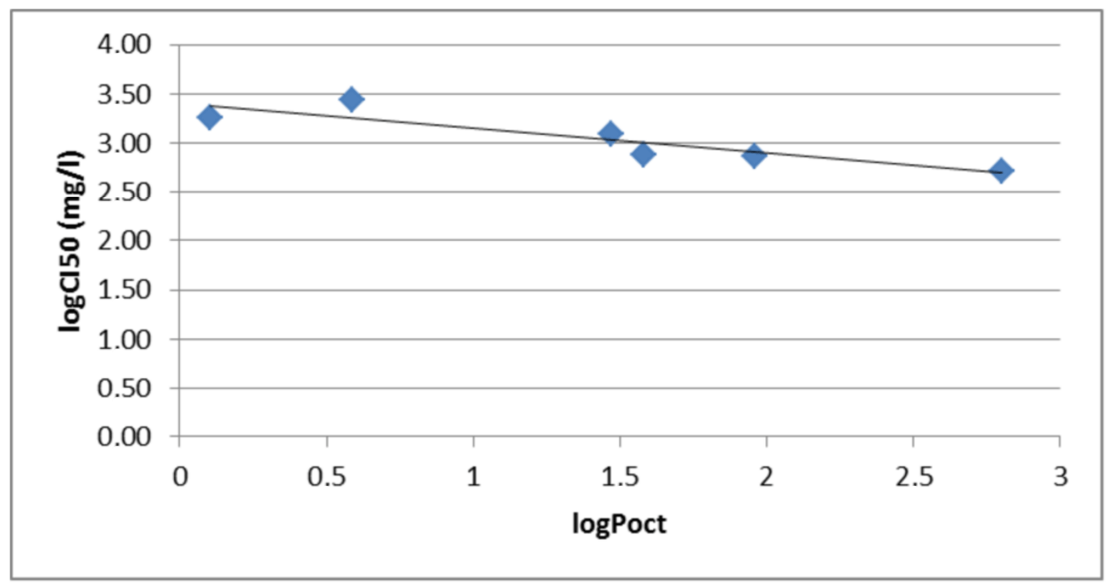

Figure 5. Effect of hydrophobicity on methanogenic toxicity for para-substituted (thio) phenols $(r=-0.94234)$.

compounds, as follows: the para-substituted toluenes (para-tolyles) and para-substituted (thio) phenols. The pNitrophénols was not included in logPoct correlation because the nitro-aromatics when present at similar concentration in the bacterial membrane exert a much higher toxic effect than that which can be accounted for by membrane toxicity alone.

Figures $\mathbf{4}$ and $\mathbf{5}$ show the correlation between the methanogenic toxicity and partition coefficient logPoct for para-substituted toluenes and para-substituted (thio) phenols, respectively.

The experimental results in this study, as well as our previous work, suggest that a direct relationship between hydrophobicity as indicated by logPoct and methanogenic toxicity can be established [15]. A significant correlation was obtained indicating that the partitioning of bisubstituted aromatic compounds into lipophilic membranes in bacteria may have a role in the toxicity.

In fact, it is known that a substitution on the aromatic ring that enhances the hydrophobicity render the molecule more toxic and that enhances the hydrophobicity of aromatic ring causes the molecule to be less toxic. According to Hansch and Leo works [16]:

$>$ hydrocarbon or halogenated substituents on the benzene ring are lipophilic in the case of $\mathrm{CH}_{3}, \mathrm{~F}, \mathrm{Cl}, \mathrm{Br}, \mathrm{I}$, $\mathrm{NO}_{2} \cdots$.

> The substituents containing electronegative atoms such as $\mathrm{O}$ and $\mathrm{N}$ are generally hydrophilic $(\mathrm{OH}, \mathrm{SH}$, $\mathrm{NH}_{2}, \mathrm{CHO}, \mathrm{COOH}, \mathrm{CONH}_{2}, \mathrm{OCH}_{3}, \mathrm{OCOCH}_{3}$ ).

The diffusion of a molecule across a membrane depends on the permeability of this membrane. However, the membrane permeability is a function of the partition coefficient $\log$ Poct (hydrophobicity). So the more hydrophobic a molecule is, the higher is its membrane permeability and the greater is its toxicity [17-19].

Thus, the higher value of logPoct of an aromatic compound indicates that the compound readily penetrates the bacterial membrane and becomes toxic. It follows: al- teration of the membrane structure, leakage of substances, the disruption of metabolism, cell degeneration and ultimately his death [10].

\section{Conclusions}

This work demonstrates that the grafting of a hydrophobic or hydrophilic substituent on the benzene or monofunctional aromatic compound, conducts to the modification of toxicity of the compound on methanogenic bacteria.

Experimental results suggest that a direct relationship between hydrophobicity as indicated by logPoct and methanogenic toxicity can be established.

\section{REFERENCES}

[1] Y. Chen, J. J. Cheng and K. S. Creamer, "Inhibition of Anaerobic Digestion Process: A Review,” Bioresource Technology, Vol. 99, No. 10, 2008, pp. 4044-4064. doi:10.1016/j.biortech.2007.01.057

[2] M. A. Martin, J. A. Siles, A. F. Chica and A. Martin, "Biomethanization of Orange Peel Waste," Bioresource Technology, Vol. 101, No. 23, 2010,pp. 8993-8999. doi:10.1016/j.biortech.2010.06.133

[3] J. L. Eze and O. Ojike, "Anaerobic Production of Biogas from Maize Wastes," International Journal of the Physical Sciences, Vol. 7 No. 6, 2012, pp. 982-987. doi:10.5897/IJPS11.1519

[4] L. A. Fdez-Gülfo, C. Alvarez-Gallego, D. Sales and L. I. Romero Garcia, "Determination of Critical and Optimum Conditions for Biomethanization of OFMSW in a SemiContinuous Stirred Tank Reactor," Chemical Engineering Journal, Vol. 171, No. 2, 2011, pp. 418-424. doi:10.1016/j.cej.2011.03.096

[5] C. Rico, J. Juis Rico, I. Tejero, N. Munoz and B. Gomez, "Anaerobic Digestion of the Liquid Fraction of Dairy Manure in Pilot Plant for Biogas Production: Residual Methane Yield of Digestate," Waste Management, Vol. 31, No. 9-10, 2011, pp. 2167-2173. 
doi:10.1016/j.wasman.2011.04.018

[6] J. Field and R. Sierra, "Waste Characteristics and Factors Affecting Reactor Performance,” IHE-Delft \& WAU, Wageningen, 1990.

[7] Y. Wang, Y. Zhang, J. Wang and L. Meng, "Effects of Volatile Fatty Acid Concentrations on Methane Yield and Methanogenic Bacteria,” Biomass and Bioenergy, Vol. 33, No. 5, 2009, pp. 848-853.

[8] C. Hechtand C. Greihl, "Investigation of the Accumulation of Aromatic Compounds during Biogas Production from Kitchen Waste,” Bioresource Technology, Vol. 100, No. 2, 2009, pp. 654-658. doi:10.1016/j.biortech.2008.07.034

[9] W. Chang, Y. Um, B. Hoffman and T. R. Pulliam Holoman, "Molecular Characterization of Polycyclic Aromatic Hydrocarbon (PAH)-Degrading Methanogenic Communities,” Biotechnology Progress, Vol. 21, No. 3, 2005, pp. 682-688. doi:10.1021/bp0495791

[10] B. A. Donlon, E. Razo-Flores, J. A. Field and G. Lettinga, "Toxicity of N-Substituted Aromatics to Acetoclastic Methanogenic Activity in Granular Sludge,” Applied and Environmental Microbiology, Vol. 61, No. 11, 1995, pp. 3889-3893.

[11] S. Kalyuzhnyi, V. Sklyar, T. Mosolova, I. Kucherenko, J. A. Russkova and N. Degtyaryova, "Methanogenic Biodegradation of Aromatic Amines," Water Science and Technology, Vol. 42, No. 5-6, 2000, pp. 383-370.

[12] R. Sierra and G. Lettinga., "The Role of Aromatic Structure on Methanogenic Toxicity,” Mededelingen Faculteit
Landbouwwetenschappen Rijksuniversiteit Gent, Vol. 4, No. 4b, 1989, pp. 1437-1474.

[13] K. Mbuyu and K. Kayembe, "Production du Méthane (Biogaz) Par la Digestion Anaérobie des Drêches de Brasseries et des Lisiers de Vaches," Reviews of Congress on Scientific Nuclear, Vol. 16, No. 2, 2000, pp. 47-62.

[14] K. Mbuyu and K. Kayembe, "Etude de la Toxicité Méthanogénique des Cations $\mathrm{K}+$ et $\mathrm{Na}+$," Reviews of Congress on Scientific Nuclear, Vol. 16, No. 2, 2000, pp. 65-76.

[15] N. Mambanzulua, K. Kayembe and V. Noki, "Détermination des Activités Méthanogènes Spécifiques des Lisiers Dans le Traitement Anaérobique des Déchets,” Mededelingen Faculteit Landbouwwetenschappen Universiteit Gent, Vol. 64, No. 1, 1999, pp. 183-188.

[16] A. Leo, C. Hansch and D. Elkins, "Partition Coefficients and Their Uses,” Chemical Reviews, Vol. 71, No. 6, 1971, pp. 525-616. doi:10.1021/cr60274a001

[17] P. T. Mpiana, "Biophysique Médicale,” Resud Edition, Kinshasa, 2010.

[18] W. B. Whitman, T. Mothy, L. Bowen and D. R. Boone, “The Methanogenic Bacteria,” Prokaryotes, Vol. 3, 2006 , pp. 165-208.

[19] H. H. P. Fang, "Inhibition of Bioactivity of UASB Biogranules by Electroplating Metals," Pure and Applied Chemistry, Vol. 69, No. 11, 1997, pp. 2426-2429. doi:10.1351/pac199769112425 